\title{
Research on the Application of Cross Border E-commerce Logistics System
}

\author{
Hongwei WANG \\ School of accountancy, \\ Harbin University of Commerce \\ Harbin, China \\ e-mail:whwdsh@126.com
}

\author{
Xiaojun LU \\ Management Practice Center, \\ Harbin University of Commerce \\ Harbin, China \\ e-mail: 1xjharbin@126.com
}

\begin{abstract}
Cross-border e-commerce is an important part of China's foreign trade, is a huge driving force for economic development and new economic growth point, but compared with the rapid development of cross-border e-commerce, logistics has become a bottleneck restricting its sustainable development. It is urgent to improve the logistics system and innovate the logistics mode to meet the requirements of the rapid development of cross-border e-commerce. Based on the analysis of the restrictive factors of infrastructure, enterprise competitiveness and logistics information, this paper puts forward some suggestions to improve the development of cross border logistics.
\end{abstract}

Keywords-cross-border; e-commerce; logistics

\section{INTRODUCTION}

In the global economic integration and the rapid development of electronic information technology today, the important status and role of cross-border e-commerce in international trade has become increasingly prominent, has become a new economic growth point, is also an important booster of economic development, is a basic and strategic role in the national economy, is the inevitable trend of the national foreign trade development. Seize the opportunity to develop cross-border e-commerce is to promote economic development and transformation and upgrading, enhance the level of opening up, guarantee the in-depth implementation of the "The Belt and Road" national strategy.

The success of cross-border e-commerce depends on the full and effective integration of logistics, capital flow and information flow. Because of the logistics cost, timeliness of delivery of goods and other factors of consumers will greatly influence consumer experience, while cross-border logistics and domestic logistics, logistics network construction cost, technology and other aspects in the channel is more complex, therefore, logistics plays an important role in cross-border ecommerce, is one of the core aspects of cross-border electronic commerce. Whether the logistics system is perfect plays an important role in the development of cross-border ecommerce.

\section{CROSS-BORDER E-COMMERCE LOGISTICS STATUS}

At present, there are a total of 60 city to carry out crossborder e-commerce business, has approved 15 city including Hangzhou, Tianjin, Shanghai, the establishment of a national comprehensive pilot area of cross-border e-commerce and cross-border e-commerce retail import pilot city. April 8, 2016, China's cross-border e-commerce retail import commodities to implement a new tax system, and the implementation of inventory management. Ministry of Commerce pointed out that China's cross-border electricity supplier after the transition period of the retail import policy expires, will take a new regulatory model from January 1, 2018, when it will be more to strengthen the main responsibility of e-commerce companies. Driven by the dual needs of the positive and favorable policies, the number and scale of cross-border e-commerce companies continue to expand, the speed of overseas logistics network layout significantly accelerated. Rookie logistics network has covered more than and 200 countries and regions worldwide, global cross-border logistics daily processing capacity of more than 4 million single, straight SF EXPRESS global coverage to nearly 250 countries and regions, starting Chinese park dragon network in Europe's biggest crossborder e-commerce industry. Cross border e-commerce logistics business showing explosive growth, has become an important growth point of China's foreign trade.

\section{MaIn Problems of Cross-border E-COMMERCE LOGISTICS}

Although cross-border e-commerce logistics gratifying results, but the business needs and the rapid development of cross-border e-commerce, in the commodity storage, logistics channel, logistics information system, there are still many deficiencies, it needs further improvement and development.

\section{A. Policies Need to be Further Improved.}

Good policy environment is the premise to promote the development of cross-border e-commerce logistics, crossborder e-commerce is conducive to efficient operation of logistics. As an emerging industry, the government has promulgated many policy documents, but the logistics related policies and regulations are relatively scarce and relates to cross-border logistics industry standard, operation standard, customs clearance procedures, tax, warehouse management and other aspects of the policy has not formed a system, standardization. In addition, there are big differences in the implementation of the guiding policy of the local government in the implementation of specific policies, many supportive policies need to be further implemented, local 
government policies and regulations still need to be improved.

\section{B. Logistics Infrastructure Needs to be Further Improved.}

Logistics channel is the foundation of the successful completion of e-commerce activities, and is the basis of logistics to adapt to the rapid development of e-commerce. Although China after decades of construction, the transportation infrastructure has been greatly improved, forming a set of aviation, railway and highway transportation system, but there are still many problems, the overall logistics environment relative to the international advanced level, and the conversion between different modes of transport connection was not convenient, supporting logistics facilities have to be perfect.

\section{Logistics Enterprises Lack of Industry Norms, Lack of Overall Competitiveness.}

Although the large number of China's logistics enterprises, but the overall situation from the industry point of view, companies generally small scale, service quality level is uneven, many logistics enterprises there are loopholes in the financial, auditing, claims and other aspects, the lack of standardized management. In addition to a small number of large-scale logistics enterprises, most of the logistics business process is in accordance with the traditional concept and mode of management, lack of effective use of third party logistics, based on high-end logistics service supply chain management is very small. The concept of logistics enterprise management and service concept, resulting in a narrow range of business management, the main single service, business is not standardized, low utilization of equipment. In addition, the logistics industry is lack of uniform industry standards, enterprises in order to be able to get customer orders and deliberately lower prices, vicious competition phenomenon is serious, disrupting the normal market order of logistics, the logistics industry associations exist, lack of execution.

\section{Low Degree of Logistics Information, the Lack of a Unified Cross-border Logistics Information Platform.}

Although information technology is increasingly popular, but many logistics enterprises only to establish a website, the basic situation in the home page lists the general situation of the enterprise, contact only, not in-depth and comprehensive understanding of the enterprise, and many sites don't even slow update of data update, the equipment utilization rate is very low, basically in the idle state.

The lack of cross-border logistics logistics information public platform, the logistics information lag, both sides cannot grasp accurately the process of logistics, which leads to an increase in the process of logistics invalid links, increase the cost of logistics operations, to the cooperation of logistics industry development caused great resistance.

\section{Suggestions to Promote the Development of CROSS-BORDER E-COMMERCE LOGISTICS}

\section{A. Improve the System of Policies and Regulations, the Development of Uniform Standards.}

On the basis of existing policies, the state will improve the cross-border logistics management policies in accordance with the objectives of macro development, so as to ensure the smooth construction and healthy development of the logistics system. On the premise of strengthening macro guidance, the policy document should be carried out in the pilot test area, exploration and innovation, summarize the experience, after the success as the standard for promotion; supervise local regulatory units according to the actual situation and formulate corresponding management measures and implementation process. At the same time, in order to encourage the development of logistics enterprises, the corresponding policy support should be given in the aspects of land use, taxation, financing and so on.

\section{B. Accelerate the Construction of Cross-border E- commerce Logistics Channel.}

For the construction of the logistics channel, we should adopt the comprehensive construction and convergence of aviation, railway and marine transportation, and form the logistics network covering the whole world. Increase the renovation and expansion of the transportation hub, improve the conversion efficiency of different modes of transport of goods; coordination with neighboring countries, and gradually unified railway standard; accelerate the process of Pakistan Economic Corridor construction project, through the Midwest e-commerce logistics channel, provide strong support for cross-border e-commerce.

\section{Establish Industry Standards, Set up Large Logistics Enterprises, Enhance the Core Competitiveness of Enterprises.}

The specification of the logistics industry, give full play to the role of the logistics industry associations, with more management functions, the development of logistics business training and assessment, keep normalization, help, and urge enterprises to improve their management functions; through the effective integration of logistics resources in accordance with the basic principles of mutual benefit and win-win, the formation of large logistics enterprises, thus enhance the core competitiveness of enterprises, the co-development of the international logistics market.

\section{To Further Promote the Construction of Logistics Information.}

In order to meet the rapid growth of cross-border ecommerce logistics information processing requirements, should vigorously strengthen the application of information technology, make full use of big data, "Internet plus", cloud computing, networking, mobile Internet and other technologies to support intelligent sorting, optimization of logistics information system and equipment is widely used in the field of electronic commerce logistics. At the same time, the domestic and overseas both sides should jointly planning 
and coordination, comprehensive solution to both sides because of application system, data format and communication protocol and other technical aspects of differences arising from data docking, multi platform and the data exchange problem, establish bilateral logistics public information platform, logistics information system docking.

\section{E. Construction of Overseas Warehouse and Border} Warehouse, Improve Logistics Storage Capacity.

With the rapid growth of cross-border logistics business, many logistics enterprises to actively build overseas positions, this is because the first overseas warehouse delivery, after sale "mode can effectively reduce logistics costs, shorten delivery period, convenient customer returns, improve customer confidence in the purchase and many other advantages, has great appeal for logistics enterprises. Overseas warehouse logistics for developed countries is more appropriate, but for Russia and other emerging ecommerce market, due to the Russian local labor costs and operating taxes are high, the operation is bound to increase the cost of overseas positions. In view of Russia and China's direct border, so we can choose in Harbin or Suifenhe, Manchuria, China and Russia border border positions, when the order form, with the help of the Russian efficient logistics channels can quickly complete customs clearance.

\section{CONCLUSION}

Despite the current cross-border e-commerce logistics still exist many problems, but the national macroeconomic environment for its development provides a huge space, only from the policy improvement and implementation, strengthen the logistics channel construction, give full play to the role of information technology and other aspects, positive innovation, in order to ensure the sustained and stable development of cross-border e-commerce logistics, provide support and sufficient protection for cross-border ecommerce.

\section{REFERENCE}

[1] China Federation of logistics and purchasing.2016 electricity supplier logistics operation analysis and 2017 outlook [DB/OL] ttp://www.chinawuliu.com.cn/lhhkx/201702/15/319121.shtml.2017$02-15$.

[2] Zhang Bin, Liu Xiaojun, Tao Zhang. Current situation and operation mode of cross border e-commerce in China. China's circulation economy [J]. 2015 (1), 51-53.

[3] Wang Nuan. The status quo and problems of research on logistics development of electronic commerce in China. Economic Research Guide [J].2016 (7), 42-43.

[4] Wang Hongwei, Lu Xiaozheng. Study on Harbin to Russia industrial economic belt construction improve the logistics system and information science. [J].2016 (6), 167-169. 